\title{
Using Genially Games for Enhancing EFL Reading and Writing Skills in Online Education
}

\author{
Luz Castillo-Cuesta \\ Universidad Técnica Particular de Loja, Loja, Ecuador
}

\begin{abstract}
The aim of this study was to determine the impact of using Genially games for enhancing English as a foreign language (EFL) reading and writing skills. The participants were 48 students from the A2 level, according to the Common European Framework of Reference for Languages (CEFR). They were enrolled in two reading and writing courses at a private university in Loja, in the south of Ecuador. The participants were organized into an experimental $(n=23)$ and a control group $(n=25)$. A mixed-method approach was used for collecting and analyzing data in this research. Pre- and post-tests were administered to all the participants; furthermore, a perceptions survey was applied to the experimental group. This study involved an online instructional process in which Genially game-based activities were implemented for practicing reading comprehension as well as paragraph and essay organization. The results showed that the use of Genially games was effective to enhance EFL reading and writing skills. An increase in the experimental group's scores was evident for the reading skills, specifically when they had to identify main ideas, supporting details, and other elements of a reading passage. Regarding writing, they showed improvement in terms of recognizing accurate grammar and vocabulary, organizing ideas, and demonstrating awareness of essay organization. Participants also had a positive perception toward the use of game-based activities, which also increased their motivation. Further research should consider planning, game design, implementation, evaluation, and feedback.
\end{abstract}

Keywords: EFL skills; Genially games; online education; reading and writing; teaching and learning

\section{Introduction}

The COVID-19 pandemic impacted all aspects of human activities, including education at all levels. Thus, elementary schools, high schools, and universities around the world had to implement online teaching, which was possible through the use of information and communication technologies (ICTs). In this context, instructors had to switch to online teaching, requiring them to apply numerous technological tools and resources to solve problems and implement new 
educational approaches (Eickelmann \& Gerick, 2020). Regarding foreign language instruction, technology plays a fundamental role (Singhal, 2004); in fact, the use of ICTs has been crucial because "technology has added new dimensions to the nature of English as a Foreign Language" (Papadima-Sophocleous et al., 2014, p. 296).

The use of ICTs for English as a foreign language (EFL) teaching has been especially relevant during the COVID-19 pandemic. Teachers have used technological tools for delivering education and ensuring that learners continue to receive teaching (Sandhu \& De Wolf, 2020). In fact, technology provides several benefits for teaching and learning linguistic skills. Among these skills, reading and writing are essential for successful language learning. As Sadiku (2015) asserted, reading brings wisdom; furthermore, it involves an interactive process to construct meaning (Shihab, 2011). Concerning writing, it is a skill that demands the instructor's care and attention when training students (Harmer, 2004). As Sadiku (2015) emphasized, "[w]riting is a gem to pick" (p. 31), because people with good writing skills will always succeed when expressing themselves.

Therefore, EFL instructors need to implement innovative strategies and activities that help students develop reading and writing skills, especially when using online settings. The use of technological resources engages learners to develop reading and writing skills and offers unlimited opportunities for practicing them. In this context, games constitute important components in EFL education (Gozcu \& Caganaga, 2016) and offer a competitive alternative for students to fully engage in learning (Mekler et al., 2016). Since there is a strong connection between gamification and emergent technologies (Figueroa, 2015), teachers need to familiarize themselves with online platforms that allow them to design digital game-based activities that are useful for language learners (Turgut \& İrgin, 2009). One of the most innovative tools to create games is Genially, which has an intuitive and easy-to-use interface that facilitates content gamification and interactive communicative experiences (González, 2019).

Regarding the use of games in EFL teaching and learning, several studies have been carried out in different educational contexts. Jassim and Dzakiria (2019) investigated the impact of digital games on students' vocabulary learning. Yavuz et al. (2020) analyzed the influence of gamified learning activities, designed in the free learning management platform Edmodo, on EFL students' writing anxiety levels. Sari et al. (2020) explored the use of games for teaching speaking to EFL learners. Nevertheless, the possibilities and benefits that Genially games offer to enhance reading and writing skills have not been explored, especially when using virtual settings during prolonged periods of lockdown. In addition, it is necessary to remark that higher education students face many challenges when reading and writing in a foreign language, which influences their academic performance. Therefore, this research constitutes a contribution to shed light on the use of Genially games for enhancing EFL reading and writing skills in online education. 
Thus, the following research questions have been formulated:

1. What is the impact of using Genially games when teaching EFL reading and writing skills?

2. How do students perceive the use of Genially games to foster EFL reading and writing skills?

\section{Literature Review}

This section includes information about the teaching challenges during online learning, the use of ICT for EFL teaching, the teaching of reading and writing, the use of gamification in EFL education, and previous research regarding the use of digital games in EFL teaching.

\subsection{Teaching Challenges During Online Learning}

COVID-19 has struck the world suddenly and with force, with all aspects of human activities being dramatically impacted by this contagious disease. Higher education institutions as well as elementary schools and high schools around the world are still being affected by the global health crisis, which caused a devastating impact on learners, teachers, and parents (Karataş \& Tuncer, 2020; König et al., 2020; Toquero, 2020). These learning disruptions decreased access to education and research facilities (Onyema et al., 2020).

In this context, educational institutions at all levels had to implement online teaching as part of the global efforts to mitigate the adverse effects of the COVID19 pandemic. Teachers faced unprecedented challenges while adapting to online teaching, trying to communicate with students, and supporting their development (König et al., 2020). According to Eickelmann and Gerick (2020), instructors had to switch to online teaching, requiring them to apply numerous technological tools and resources to solve problems and implement new educational approaches. As Toquero (2020) acknowledged, for online education delivery, instructors need ICT skills to plan, implement activities, and evaluate learners' performance. Thus, the adoption of ICTs in education was and is inevitable.

\subsection{ICT for Teaching English as a Foreign Language}

Language teaching can be improved by the appropriate use of technology (Hoopingarner, 2009), which offers new opportunities for successful language learning (Kumar \& Tammelin, 2008) and increases learners' interest, attention, and motivation (Cabrera-Solano, 2020; Saravanakumar, 2018). In the case of EFL teaching and learning, the use of ICT has been crucial; as Singhal (2004) acknowledged, technology and foreign language education are related to each other. According to Papadima-Sophocleous et al. (2014), "technology has added new dimensions to the nature of English as a Foreign Language" (p. 296). In addition, they asserted that language teachers should have pre-service instruction that includes the use of technological tools for language educational purposes. In fact, integrating the use of ICT for training pre-service teachers is an essential aspect that all education stakeholders should consider (Bahcivan et al., 2019). 
The role of ICT for EFL teaching has been especially relevant during the COVID19 pandemic. Teachers have used technological tools for delivering education and ensuring that learners continue to receive teaching (Sandhu \& De Wolf, 2020). They have thus tried to meet students' needs and showed that "[e]ven though schools have closed, learning has not ended" (Carver, 2020, p. 129). In fact, technology provides several benefits for EFL instructors and learners. Social networking sites have been recognized as efficient tools to enhance all language skills (Nugroho \& Rahmawati, 2020), while digital games have been linked to improvement in terms of language acquisition (Castillo-Cuesta, 2020). Furthermore, EFL learners consider that web-based activities are helpful to learn course content (Kirovska-Simjanoska, 2019). Using ICT is also beneficial for EFL students because it allows them to communicate with native and non-native speakers around the globe and provides a diversity of resources to develop their skills and to become active learners (Isisag, 2012).

\subsection{Teaching EFL Reading and Writing}

Reading and writing are essential skills for successful language learning. According to Harmer (2007), reading is indispensable for language acquisition and has a positive influence on learners' knowledge of vocabulary and spelling. Nation and Macalister (2020) stated that "reading is a source of learning and a source of enjoyment" (p. 49). They have thus acknowledged that reading might be conceived as an aim and also as a way to accomplish other academic aims. Reading certainly brings wisdom (Sadiku, 2015) and involves an interactive process to construct meaning (Shihab, 2011). Likewise, for writing, Sadiku (2015) emphasized that "[w]riting is a gem to pick" (p. 31), because people with good writing skills will always succeed when expressing themselves. This skill has also been regarded as an essential device to demonstrate creativity and personal discovery (Ghufron \& Ermawati, 2018) and as a crucial element of success at all educational levels and professional contexts (Çelik, 2016). Writing has been considered a fundamental and challenging skill (Cabrera et al., 2014) as well as a means to express ideas, which demands instructors' attention when training students (Harmer, 2004).

Since reading and writing skills are crucial for language learning, EFL teachers need to understand that reading and writing are strongly linked because they seem to be constructed on the same linguistic and metacognitive knowledge resources (Schoonen, 2019). In fact, reading resources offer good models for writing because they allow teachers to demonstrate the way sentences, paragraphs, and whole texts are constructed (Harmer, 2007), especially in online education. Learners spend a lot of time reading and communicating online for educational purposes and personal enjoyment (Marboot et al., 2020). This online environment provides unlimited opportunities for them to practice their skills. Nevertheless, students need teachers' support. Students can use certain media to develop their writing skills (Kharis et al., 2020) and they can receive timely feedback through technological tools (Isisag, 2012). In this context, EFL instructors need to implement innovative strategies, activities, and technological resources that can engage learners so that they can develop reading and writing skills. 


\subsection{Gamification in EFL Education}

Games, which include activities that involve goals, rules, and fun, have been considered as very important components in EFL education (Gozcu \& Caganaga, 2016). According to Sørensen and Meyer (2007), games are useful to encourage motivation and authentic communicative practices in the language classroom. In addition, they offer an engaging platform where students can be involved in learning (Mekler et al., 2016). Certainly, gamification reduces anxiety, increases positive feelings, and improves learners' self-confidence when practicing the target language. Therefore, games can be recognized as learner-centered activities that provide opportunities for active participation (Mekler et al., 2016). Among the advantages of using games in EFL contexts, Deesri (2002) emphasized that they catch learners' attention, lower stress levels, and give students the chance for real communication; however, teachers need to carefully select games that actually meet students' needs in terms of age, language level, and time to be implemented.

Nowadays, the term gamification is increasingly being used in EFL education and other fields. As Deterding et al. (2011) stated: "Gamification is an informal umbrella term for the use of video game elements in non-gaming systems to improve user experience (UX) and user engagement" (p. 2425). Furthermore, gamification has been valued as a learning technique that transfers game mechanisms to the academic area (Alhalafawy \& Zaki, 2019). According to Antonaci et al. (2019), the design, application, and usefulness of games depend on the users and the setting of the implementation; thus, it is necessary to consider the outcomes of an explicit gamification component in a specific scenario and audience. Since there is a strong connection between gamification and emergent technologies (Figueroa, 2015), teachers need to familiarize themselves with online platforms that allow them to design digital game-based activities that are useful for language learners (Turgut \& İrgin, 2009). There are several technological resources for implementing gamification, such as Educaplay, Gamilab, Kahoot, Quizizz, and Blended Play. However, one of the most innovative platforms to create games is Genially, which has an intuitive and easy-to-use interface that facilitates content gamification and interactive communicative experiences (González, 2019).

\subsection{Studies of Digital Games in EFL}

Zheng et al. (2015) examined the acquisition of vocabulary through a quest game designed in English between a Japanese learner and a native speaker of English. The study explains how participants embodied in their avatars took semiotic resources imbued in World of Warcraft, a massively multiplayer online game (MMOG). Through interactive multimodal analysis, vocabulary acquisition was significant as the researchers examined both chat and avatar action information. The results demonstrated that the use of online games facilitates language learning and enhances problem-solving skills.

Calvo-Ferrer (2017) studied the influence of the didactic game The Conference Interpreter on second language vocabulary learning and perceived learning gains, as compared with a non-gaming resource that reproduced its contents. The participants were 65 English as a second language (ESL) students who were 
divided into control and experimental groups; they took pre-, post-, and delayed tests. The results evidenced that the participants who had access to the contents via the video game performed better in the short run, found the materials more attractive, and had improved vocabulary knowledge than those in the control group.

Jassim and Dzakiria (2019) carried out a study to review literature regarding the impact of digital games on students' vocabulary learning. The objective was to shed light on the challenges and benefits of the use of gamification for acquiring EFL vocabulary. They found that most of the studies emphasized motivation and cooperation as significant benefits among learners. Furthermore, they concluded that teachers must consider time and materials when selecting or designing a game.

Yavuz et al. (2020) analyzed the influence of Edmodo gamified learning activities on EFL students' writing anxiety levels. The participants were 47 university students who took writing instruction. An experimental design was used and the researchers collected data by means of a background questionnaire and the Second Language Writing Anxiety Scale. The SPSS program was used to analyze data. The results evidenced that the learners who completed assignments using Edmodo experienced significantly lower anxiety levels than those who used the old-fashioned pen and paper to complete their assignments.

Sari et al. (2020) investigated English teachers' efforts in using games for the teaching of speaking and the implementation problems they faced. The participants included 30 adolescents and two teachers who were observed during four classes and then had to complete a questionnaire. The results showed that the challenges faced by teachers were related to preparation, participation, and class management. Thus, it is suggested that appropriate planning, better class management, and a focus on the learners' participation are required to implement gamification in large classes.

\section{Method}

\subsection{Setting and Participants}

This study included 48 EFL students enrolled in two reading and writing distance courses of the English major program at Universidad Técnica Particular de Loja, southern Ecuador. Their ages ranged between 20 and 45 years and their proficiency level was A2 according to the Common European Framework of Reference for Languages (CEFR). The participants were organized into two groups; the experimental group included 23 students and the control group 25.

\subsection{Research Instruments}

A pre-test was administered through the Canvas platform to determine the participants' reading and writing skills. It included a reading comprehension section with four multiple-choice items and four matching tasks; also, participants had to write a brief essay in the writing section. In addition, a writing rubric was structured to monitor and assess aspects related to participants' use of grammar and vocabulary as well as their abilities to organize main ideas and supporting 
details in academic essays. In addition, a post-test, with similar characteristics as the pre-test, was applied to measure the participants' level of improvement in comparison with the pre-test results. Finally, a student perceptions questionnaire was used to gather information about participants' experience with Genially games for improving EFL reading and writing skills. It consisted of eight items that elicited responses on a Likert scale.

\subsection{Procedure}

A mixed-method approach was used to collect and analyze data in this study, which was carried out during a five-month academic term. In education, the mixed-method approach has been recognized because of the opportunities it provides to influence ideas and practices for teaching and learning (Suter, 2011).

The methodological procedure has been synthesized as presented in Figure 1.

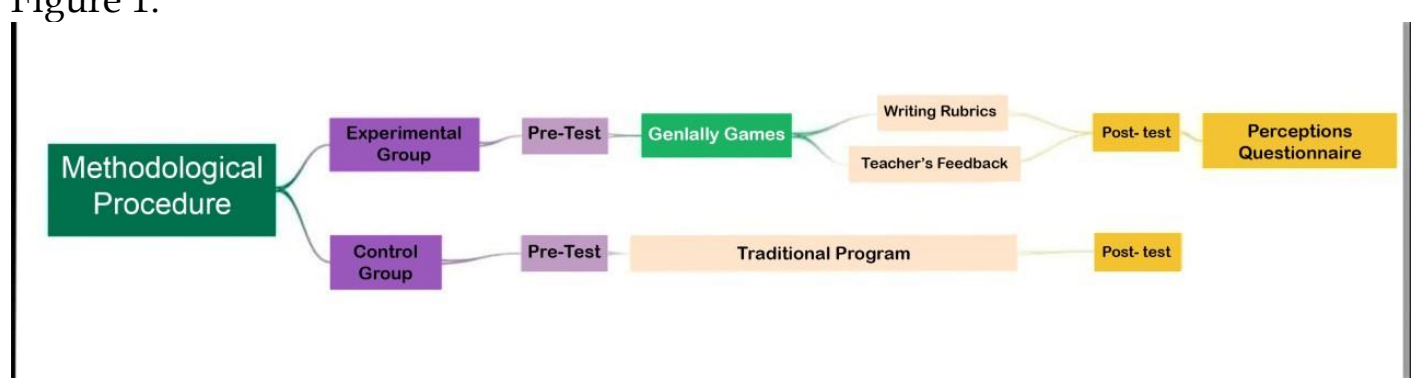

Figure 1: Methodological procedure

Before the intervention, the experimental and control groups were purposefully selected. In this case, purposive sampling was used since it involves participants who possess specific characteristics. Participants in both groups took a pre-test in the institutional Canvas platform to demonstrate their reading and writing skills. In the reading comprehension section, which included multiple-choice questions and matching tasks, participants had to analyze a reading passage, identify the main idea, find supporting details, and recognize vocabulary in context. In the writing section, participants had to write a brief essay about their hometown.

After analyzing the pre-test results and participants' needs, an intervention with 12 game-based activities designed in Genially was implemented for the participants in the experimental group. These games were thus produced taking into consideration the contents of the academic plan and were shared through the Canvas virtual platform. During this intervention, participants were invited to play voluntarily; nevertheless, the teacher emphasized the importance of practicing with games to improve their skills in the target language. The games included activities in which the participants had the opportunity to practice reading comprehension skills as well as paragraph and essay organization. As for the reading skills, participants practiced with games that required them to identify main ideas, supporting details, as well as topic and concluding sentences. For practicing their writing skills, other games were designed to help participants recognize grammatical structures, identify vocabulary in context, choose the appropriate transitions in a paragraph, and demonstrate their awareness of essay organization. During the implementation, the participants received permanent feedback; furthermore, weekly tutorials were offered through Zoom synchronous meetings. 
After the intervention, a post-test was administered to both experimental and control groups to determine the participants' level of improvement in comparison with the pre-test results. For evaluating students' production in the writing section, a rubric was used to monitor the participants' use of grammatical structures and vocabulary, as well as their skills for organizing all the components of their paragraphs and essays. Also, a perceptions questionnaire was employed to identify the experimental group's views on the use of Genially games to foster EFL reading and writing skills. Finally, it is important to remark that all the instruments were piloted and validated with similar groups of students before their administration.

\section{Results and Discussion}

This section has been articulated along the aforementioned research questions. Regarding the pre-test, the results showed participants' reading comprehension and writing skills before the implementation of games. The participants in the experimental group obtained an average of 6.81 points out of 10 points and the control group 6.65 points. Therefore, we can observe that there was not a significant difference between the mean scores of both groups $(t=0.3062$, $p=0.7609$ ). Nevertheless, these results were considered when planning and designing the game-based activities to be implemented.

As for the post-test results, Table 1 shows that the participants in the experimental group significantly increased their scores $(t=2.4390, p=0.0186)$. These results show that the use of Genially games helped the participants in the experimental group enhance their reading and writing skills. Concerning the participants in the control group, the increase in the post-test scores might be attributed to the regular teaching process.

Table 1: Results of the post-test in the experimental and control groups

\begin{tabular}{|c|c|c|}
\hline \multicolumn{3}{|c|}{ Post-test } \\
\hline Group & Experimental & Control \\
\hline Mean & 8.3735 & 7.2244 \\
\hline SD & 1.3727 & 1.8355 \\
\hline \multicolumn{2}{|c|}{$\mathrm{p}=0.0186$} \\
\hline
\end{tabular}

These results demonstrate that the game-based activities implemented were effective in improving EFL reading and writing skills among the participants of the experimental group. Thus, a positive impact of using Genially games was evident because the games fostered the development of the aforementioned skills. In this regard, the results are aligned with previous research that explored the effectiveness of gamification for enhancing EFL skills (Calvo-Ferrer, 2017; Sari et al., 2020; Yavuz et al., 2020). 
With respect to the experimental group perceptions regarding the use of Genially games to foster their reading and writing skills, results are displayed in Table 2.

Table 2: Participants' perceptions of the use of Genially games

\begin{tabular}{|l|l|l|l|l|l|}
\hline Statement & $\begin{array}{l}\text { Strongly } \\
\text { agree }\end{array}$ & Agree & Neutral & Disagree & $\begin{array}{l}\text { Strongly } \\
\text { disagree }\end{array}$ \\
\hline $\begin{array}{l}\text { Access to Genially games was easy } \\
\text { through the institutional Canvas } \\
\text { Learning Management Platform. }\end{array}$ & $52.17 \%$ & $34.78 \%$ & $8.70 \%$ & $4.35 \%$ & $0 \%$ \\
\hline $\begin{array}{l}\text { Genially games had an attractive } \\
\text { and engaging interface to practice } \\
\text { reading and writing skills. }\end{array}$ & $52.17 \%$ & $34.78 \%$ & $4.35 \%$ & $8.70 \%$ & $0 \%$ \\
\hline $\begin{array}{l}\text { The use of Genially games } \\
\text { improved my EFL reading } \\
\text { comprehension. }\end{array}$ & $73.91 \%$ & $13.04 \%$ & $4.35 \%$ & $8.70 \%$ & $0 \%$ \\
\hline $\begin{array}{l}\text { The use of Genially games } \\
\text { improved my ability to write and } \\
\text { organize ideas in paragraphs and } \\
\text { essays. }\end{array}$ & $60.87 \%$ & $26.08 \%$ & $4.35 \%$ & $4.35 \%$ & $4.35 \%$ \\
\hline $\begin{array}{l}\text { The use of Genially games } \\
\text { improved my grammar } \\
\text { knowledge. }\end{array}$ & $65.21 \%$ & $21.74 \%$ & $4.35 \%$ & $4.35 \%$ & $4.35 \%$ \\
\hline $\begin{array}{l}\text { The use of Genially games } \\
\text { improved my vocabulary } \\
\text { knowledge. }\end{array}$ & $73.91 \%$ & $17.39 \%$ & $4.35 \%$ & $4.35 \%$ & $0 \%$ \\
\hline $\begin{array}{l}\text { The teacher's feedback after } \\
\text { playing Genially games helped me } \\
\text { improve my reading and writing } \\
\text { skills. }\end{array}$ & $65.21 \%$ & $17.39 \%$ & $8.70 \%$ & $4.35 \%$ & $4.35 \%$ \\
\hline $\begin{array}{l}\text { The use of Genially games was } \\
\text { motivating for enhancing my } \\
\text { reading and writing skills. }\end{array}$ & $60.87 \%$ & $30.43 \%$ & $4.35 \%$ & $4.35 \%$ & $0 \%$ \\
\hline
\end{tabular}

Regarding the results of the perceptions questionnaire, most of the participants $(86.95 \%)$ strongly agreed and agreed that access to Genially games was not complicated by means of the institutional Canvas Learning Management Platform. Similarly, most of them $(86.95 \%)$ perceived that these games had an attractive interface that engaged them to practice reading and writing. In this respect, Genially has a friendly and intuitive interface that fosters student engagement and participation (González, 2019). Furthermore, Okada et al. (2019) asserted that one of the main requirements in game design is its ease of use, which must be accompanied by pedagogical strategies to determine students' achievements and difficulties.

With respect to the use of Genially games to improve EFL reading comprehension skills, $73.91 \%$ of the participants strongly agreed and $13.04 \%$ agreed with this statement, whereas $4.35 \%$ were neutral and $8.70 \%$ disagreed. Participants clearly 
had the opportunity to practice identifying main ideas, supporting details, and other elements of a reading passage while they were playing the games. In fact, games have a positive effect on students' linguistic skills and a significant impact on their learning strategies (Blume, 2020). Nevertheless, when using games, it is necessary to pay attention to the design, planning, and implementation process to guarantee their effectiveness, especially when teaching EFL reading (Rodriguez, 2018).

As for the use of Genially games to enhance the participants' ability to write and organize ideas in paragraphs and essays, $60.87 \%$ strongly agreed and $26.08 \%$ agreed, whereas the rest of the opinions were equally divided into neutral, disagreement, and strong disagreement ( $4.35 \%$ each). In fact, some of the game-based activities involved recognizing appropriate transitions in a paragraph and demonstrating awareness of essay organization. As Sermsook et al. (2020) acknowledged, the use of games encourages learners to develop their writing skills in English by generating enjoyable learning environments, thus ensuring that students become involved in their own learning. Regarding the implementation of gamification to improve the knowledge of grammar and vocabulary, $86.95 \%$ of the participants agreed that Genially games helped them improve their grammar, whereas $91.3 \%$ mentioned that these activities helped them enhance their knowledge of vocabulary. This shows that games can certainly help students learn vocabulary effectively (Castillo-Cuesta, 2020). Nevertheless, when designing or choosing a game, it is necessary to consider time and materials, which should be selected appropriately taking into account students' proficiency level, interest, and context (Jabbarova, 2020).

In addition, the participants expressed their perceptions regarding the benefits of feedback, with $82.6 \%$ agreeing because they perceived that feedback helped them improve their reading and writing skills. It is necessary to remark that permanent feedback was offered considering the elements of the writing rubric. In fact, when implementing educational games, feedback is beneficial for reducing redundant cognitive processes and providing students with schemas to help them correct their comprehension errors (Clark \& Mayer., 2016).

Finally, the participants' opinions with respect to the use of Genially games and their impact on motivation were significantly positive, with $91.3 \%$ acknowledging that these games motivated them to enhance their reading and writing skills. The incorporation of games in the classroom evidently allows students to take on different challenges that activate their intrinsic motivation and help them learn while interacting and having fun (Kostikova, 2017). Game-based activities are amusing and interesting; furthermore, they are highly motivating since students can use them in many types of communication tasks that enhance all language skills.

\section{Conclusions}

The use of Genially games was effective to enhance the EFL reading and writing skills of participants. There was an increase in participants' scores favoring those 
in the experimental group, which indicates the positive impact of game-based activities on their academic performance.

The implementation of game-based activities motivates learners to improve their reading and writing skills. Easy access through an interactive virtual platform, and an attractive interface constitute engaging features EFL students value while using Genially games for learning. Thus, these features foster learner commitment and participation.

EFL learners have positive perceptions toward the use of game-based activities for enhancing reading comprehension skills because they can practice identifying main ideas, supporting details, and other elements of a reading passage while they play games. In fact, games allow students to improve reading and other linguistic skills.

Genially games are useful to help students enhance their writing skills. Thus, recognizing and using correct grammatical structures, identifying appropriate transitions, organizing ideas in paragraphs, and demonstrating awareness of essay organization are some of the game-based activities that can effectively develop writing skills. When students play these games, they can also increase their vocabulary knowledge, which fosters their writing skills.

Permanent feedback is an essential aspect to be considered when implementing game-based activities to enhance EFL learners' reading and writing skills. Feedback based on rubrics allows teachers to provide timely instructions and clarify students' doubts so that they can overcome their weaknesses.

Although the number of participants and the lockdown conditions due to the COVID-19 pandemic might represent limitations regarding this work, the findings constitute a starting point for future studies that focus on the use of game-based activities for enhancing linguistic skills. In addition, since the results of this study are limited to a specific population, it can therefore not be generalized to other contexts. Further research should consider teachers' perceptions regarding planning, game design, implementation, evaluation, and feedback. Finally, further implementations of this study might also include listening and speaking skills that can be improved through the use of game-based activities.

\section{Acknowledgement}

This work was supported by Universidad Técnica Particular de Loja. The author would like to acknowledge this institution for funding research projects through the EFL Learning, Teaching and Technology Research Group.

\section{References}

Alhalafawy, W., \& Zaki, M. (2019). The effect of mobile digital content applications based on gamification in the development of psychological well-being. International Journal of Interactive Mobile Technologies, 13(8), 107-122.

https://doi.org/10.3991/ijim.v13i08.10725 
Antonaci, A., Klemke, R., \& Specht, M. (2019). The effects of gamification in online learning environments: A systematic literature review. Informatics, 6(3), 32. https://doi.org/10.3390/informatics6030032

Bahcivan, E., Gurer, M., Yavuzalp, N., \& Akayoglu, S. (2019). Investigating the relations among pre-service teachers' teaching/learning beliefs and educational technology integration competencies: A structural equation modeling study. Journal of Science Education and Technology, 28(5), 579-588. https://doi.org/10.1007/s10956-019-09788-6

Blume, C. (2020). Games people (don't) play: An analysis of pre-service EFL teachers' behaviors and beliefs regarding digital game-based language learning. Computer Assisted Language Learning, 33(1-2), 109-132. https:// doi.org/10.1080/09588221.2018.1552599

Cabrera-Solano, P. (2020). The use of digital portfolios to enhance English as a foreign language speaking skills in higher education. International Journal of Emerging Technologies in Learning (iJET), 15(24), 159-175.

https://doi.org/10.3991/ijet.v15i24.15103

Cabrera, P., González, P., Ochoa, C., Quiñónez, A., Castillo, L., Solano, L., \& Arias, M. (2014). Spanish interference in EFL writing skills: A case of Ecuadorian senior high schools. English Language Teaching, 7(7), 40-48.

http://dx.doi.org/10.5539/elt.v7n7p40

Calvo-Ferrer, J. (2017). Educational games as stand-alone learning tools and their motivational effect on L2 vocabulary acquisition and perceived learning gains. British Journal of Educational Technology, 48(2), 264-278. https://doi.org/10.1111/bjet.12387

Carver, L. (2020). Supporting learners in a time of crisis. Advances in Social Sciences Research Journal, 7(4), 129-136. https://doi.org/10.14738/assrj.74.8109

Castillo-Cuesta, L. (2020). Using digital games for enhancing EFL grammar and vocabulary in higher education. International Journal of Emerging Technologies in Learning (iJET), 15(20), 116-129. https:// doi.org/10.3991/ijet.v15i20.16159

Çelik, S. (2016). Wiki Effect on English as a foreign language writing achievement. Online Submission, 6(4), 218-227. https://files.eric.ed.gov/fulltext/ED573959.pdf

Clark, R., \& Mayer, R. (2016). E-learning and the science of instruction: Proven guidelines for consumers and designers of multimedia learning. John Wiley \& Sons.

Deesri, A. (2002). Games in the ESL and EFL class. The Internet TESL Journal, 8(9), 1-5. http://iteslj.org/Techniques/Deesri-Games.html

Deterding, S., Sicart, M., Nacke, L., O'Hara, K., \& Dixon, D. (2011). Gamification. using game-design elements in non-gaming contexts. In CHI EA '11: HI'11 Extended Abstracts on Human Factors in Computing Systems (pp. 2425-2428). https://doi.org/10.1145/1979742.1979575

Eickelmann, B., \& Gerick, J. (2020). Lernen mit Digitalen Medien: Zielsetzungen in Zeiten von Corona und unter besonderer Berücksichtigung von Sozialen Ungleichheiten [Learning with digital media: Objectives in times of corona and under special consideration of social inequities]. Die Deutsche Schule, 16, 153-162. doi:10.31244/9783830992318.09

Figueroa, J. (2015). Using gamification to enhance second language learning. Digital Education Review, (27), 32-54.

https://dialnet.unirioja.es/servlet/articulo?codigo $=5495904$

Ghufron, M., \& Ermawati, S. (2018). The strengths and weaknesses of cooperative learning and problem-based learning in EFL writing class: Teachers' and students' perspectives. International Journal of Instruction, 11(4), 657-672. https://doi.org/10.12973/iji.2018.11441a 
González, M. (2019). Genially. Genial interactive books [TRANSLATION]. Instituto Nacional de Tecnologías Educativas y de Formación del Profesorado (INTEF). https://doi.org/ 10.4438/2695-4176_OTEpdf10_2019_847-19-134-3

Gozcu, E., \& Caganaga, C. K. (2016). The importance of using games in EFL classrooms. Cypriot Journal of Educational Sciences, 11(3), 126-135.

https://files.eric.ed.gov/fulltext/EJ1140747.pdf

Harmer, J. (2004). How to teach writing. Pearson Education.

Harmer, J. (2007). How to teach English. Pearson Education.

Hoopingarner, D. (2009). Best practices in technology and language teaching. Language and Linguistics Compass, 3(1), 222-235. https://doi.org/10.1111/j.1749818X.2008.00123.x

Isisag, K. (2012). The positive effects of integrating ICT in foreign language teaching. In International Conference Proceedings. ICT for Language Learning. https://conference.pixelonline.net/conferences/ICT4LL2012/common/download/Paper_pdf/235IBT107-FP-Isisag-ICT2012.pdf

Jabbarova, A. (2020). The role of games in teaching English language. Архив Научных Публикаций JSPI. https://phys-tech.jspi.uz/index.php/ruslit/article/view/1828

Jassim, L., \& Dzakiria, H. (2019). A literature review on the impact of games on learning English vocabulary to children. International Journal of Language and Literary Studies, 1(1), 47-53. https:/ / doi.org/10.36892/ijlls.v1i1.22

Karataş, T., \& Tuncer, H. (2020). Sustaining language skills development of pre-service EFL teachers despite the COVID-19 interruption: A case of emergency distance education. Sustainability, 12(19), 8188. https://doi.org/10.3390/su12198188

Kharis, M., Ebner, M., Wijayati, P., Hidayat, E., \& Afifah, L. (2020). Microblogging with Padlet: Students' new writing experience on A2-B1 Common European Framework of Reference for Languages (CEFR). International Journal of Emerging Technologies in Learning (iJET), 15(1), 176-187. https://doi.org/10.3991/ijet.v15i01.11804

Kirovska-Simjanoska, D. (2019). Digital vs in-person learning environment in ESP classrooms: Let the students decide. Seeu Review, 14(1). https:// doi.org/10.2478/seeur-2019-0004

König, J., Jäger-Biela, D., \& Glutsch, N. (2020). Adapting to online teaching during COVID-19 school closure: Teacher education and teacher competence effects among early career teachers in Germany. European Journal of Teacher Education, 43(4), 608-622. https:// doi.org/10.1080/02619768.2020.1809650

Kostikova, I. (2017). Language games in teaching English. Theory and methods of teaching and breeding , 43, 174-184. https://doi.org/10.5281/zenodo.1243599

Kumar, S., \& Tammelin, M. (2008). Integrating ICT into language learning and teaching. Johannes Kepler Universität Linz.

https://www.researchgate.net/publication/255583982_Integrating_ICT_into_la nguage_learning_and_teaching

Marboot, K., Roohani, A., \& Mirzaei, A. (2020). Investigating Iranian EFL students' metacognitive online reading strategies, critical thinking, and their relationship: A mixed-methods study. Issues in Language Teaching, 9(1), 151-182. https://doi: 10.22054/ilt.2020.50833.475

Mekler, E., Rank, S., Steinemann, S., Birk, M., \& Iacovides, I. (2016). Designing for emotional complexity in games: The interplay of positive and negative affect. In Proceedings of the 2016 Annual Symposium on Computer-Human Interaction in Play 
Companion Extended Abstracts (pp. 367-371).

https:// doi.org/10.1145/2968120.2968126

Nation, I., \& Macalister, J. (2020). Teaching ESL/EFL reading and writing. Routledge.

Nugroho, A., \& Rahmawati, A. (2020). Let's write a caption: Utilizing Instagram to enhance ESP students' writing skills. Jurnal Basis, 7(1), 1-12. https:// doi.org/10.33884/basisupb.v7i1.1782

Okada, A., Kowalski, R, Kirner, C., \& Torres, P. (2019). Factors influencing teachers' adoption of AR inquiry games to foster skills for responsible research and innovation. Interactive Learning Environments, 27(3), 324-335. https:// doi.org/10.1080/10494820.2018.1473257

Onyema, E. M., Eucheria, N. C., Obafemi, F. A., Sen, S., Atonye, F. G., Sharma, A., \& Alsayed, A. O. (2020). Impact of coronavirus pandemic on education. Journal of Education and Practice, 11(13), 108-121. https://doi.org/10.7176/JEP/11-13-12

Papadima-Sophocleous, S., Giannikas, C., \& Kakoulli-Constantinou, E. (2014). ICT in EFL: The global effect of new technologies in the language classroom. In Proceedings of the 2014 EUROCALL Conference CALL Design: Principles and Practice (pp. 296-300). https://doi.org/10.14705/rpnet.2014.000234

Rodriguez, C. (2018). Gamificación en educación superior: Experiencia innovadora para motivar estudiantes y dinamizar contenidos en el aula. [Gamification in higher education: Innovative experience to motivate students and stimulate content in the classroom]. Edutec: Revista Electrónica de Tecnología Educativa, (63), 29-41. https:// doi.org/10.21556/edutec.2018.63.927

Sadiku, L. (2015). The importance of four skills reading, speaking, writing, listening in a lesson hour. European Journal of Language and Literature, 1(1), 29-31. https://doi.org/10.26417/ejls.v1i1.p29-31

Sandhu, P., \& De Wolf, M. (2020). The impact of COVID-19 on the undergraduate medical curriculum. Medical Education Online, 25(1), 1764740. https://doi.org/10.1080/10872981.2020.1764740

Saravanakumar, A. (2018). Role of ICT on enhancing quality of education. International Journal of Innovative Science and Research Technology, 3(12), 717-719. https://www.researchgate.net/publication/330778182_Role_of_ICT_on_Enhan cing_Quality_of_Education

Sari, D., Yusuf, Y., Darniati, N., \& Fajrina, D. (2020). Boosting young EFL students' speaking through game activities. Elementary Education Online, 19(2), 436-444. https://doi:10.17051/ilkonline.2020.689664

Schoonen, R. (2019). Are reading and writing building on the same skills? The relationship between reading and writing in L1 and EFL. Reading and Writing, 32(3), 511-535. https:// doi.org/10.1007/s11145-018-9874-1

Sermsook, K., Liamnimitr, J., \& Chantarangkul, V. (2020). Promoting Thai EFL learners' ability to self-correct errors in written English sentences through games. English Language Teaching, 13(6), 118-126. https://doi.org/10.5539/elt.v13n6p118

Shihab, I. (2011). Reading as critical thinking. Asian Social Science, 7(8), 209-218. https://doi.org/10.5539/ass.v7n8p209

Singhal, M. (2004). The internet and foreign language education: Benefits and challenges. Teaching English as a Second Language Journal, 53(3), 241-267. http:/ /iteslj.org/Articles/Singhal-Internet.html

Sørensen, B., \& Meyer, B. (2007). Serious games in language learning and teaching: A theoretical perspective. In DiGRA Conference (pp. 559-566). http://www.digra.org/wp-content/uploads/digital-library/07312.23426.pdf

Suter, W. (2011). Introduction to educational research: A critical thinking approach. Sage. 
Toquero, C. (2020). Challenges and opportunities for higher education amid the COVID-19 pandemic: The Philippine context. Pedagogical Research, 5(4), em0063. https://doi.org/10.29333/pr/7947

Turgut, Y., \& İrgin, P. (2009). Young learners' language learning via computer games. Procedia - Social and Behavioral Sciences, 1(1), 760-764. https://doi.org/10.1016/j.sbspro.2009.01.135

Yavuz, F., Ozdemir, E., \& Celik, O. (2020). The effect of online gamification on EFL learners' writing anxiety levels: A process-based approach. World Journal on Educational Technology: Current Issues, 12(2), 62-70.

https://doi.org/10.18844/wjet.v12i2.4600

Zheng, D., Bischoff, M., \& Gilliland, B. (2015). Vocabulary learning in massively multiplayer online games: Context and action before words. Educational Technology Research and Development, 63(5), 771-790.

https://doi.org/10.1007/s11423-015-9387-4 